\title{
EFEKTIFITAS PEMBELAJARAN MODEL CONTEXTUAL TEACHING DAN SAINS TEKNOLOGI MASYARAKAT TERHADAP HASIL BELAJAR MAHASISWA
}

\author{
Hastuti Diah Ikawati ${ }^{1}$, Zul Anwar ${ }^{2}$, Nila Egidia Safitri ${ }^{3}$ \\ IKIP Mataram ${ }^{1,2,3}$ \\ hastutidiahikawati@ikipmataram.ac.id ${ }^{1}$
}

\begin{abstract}
ABSTRAK
Penelitian ini bertujuan untuk mengetahui efektifitas model pembelajaran contextual teaching learning dan model sains teknologi masyarakat terhadap hasil belajar mahasiswa pada mata kuliah difusi inovasi pendidikan. Penelitian ini menggunakan eksperiment sетu dengan pengumpulan data menggunakan tes, dokumentasi, wawancara dan observasi. Hasil penelitian menunjukkan bahwa nilai rata-rata hasil belajar mahasiswa yang digunakan pembelajaran model sains teknologi masyarakat lebih tinggi dibanding dengan nilai hasil belajar mahasiswa yang digunakan model contextual teaching learning. Ini disebabkan karena model sains teknologi masyarakat membantu mahasisiswa lebih memahami materi terkait dengan permasalahan yang ditemukan dikehidupan nyata sehingga peserta didik menjadi aktif dalam proses pembelajaran. Simpulan, model pembelajaran Contextual Teaching dan Sains teknologi masyarakat lebih efektif meningkatkan hasil belajar mahasiswa pada matakuliah difusi inovasi pendidikan.
\end{abstract}

Kata Kunci: Hasil Belajar, Model Contecxtual Teaching Learning, Sains Teknologi Masyarakat.

\begin{abstract}
This study aims to determine the effectiveness of contextual teaching learning models and community technology science models on student learning outcomes in the diffusion courses of educational innovation. This study uses quasiexperimental by collecting data using tests, documentation, interviews and observations. The results showed that the average value of student learning outcomes used in the learning model of community technology science was higher than the value of student learning outcomes used in the contextual teaching learning model. This is because the community's science technology model helps students better understand material related to problems found in real life so students become active in the learning process. In conclusion, the Contextual Teaching and Science learning model of community technology is more effective in improving student learning outcomes in the diffusion of education innovation courses.
\end{abstract}

Keywords: Learning Outcomes, Contextual Teaching Learning Model, Science Technology Society. 


\section{PENDAHULUAN}

Teknologi Pendidikan merupakan suatu pengembangan, implementasi dan penilaian terhadap sistem-sistem, teknik, dan alat bantu dalam memperbaiki dan meningkatkan proses belajar mengajar. Dalam hal ini yang diutamakan yakni proses belajar dan alat-alat yang dapat mebantu proses belajar dan pembelajaran. Sebab itulah teknologi pendidikan terkait dengan software maupun hardwarenya. Software berupa menganalisis dan mendesain langkah-langkah atau prosedur dalam pembelajaran berdasarkan tujuan yang ingin dicapai dengan metode penyajian serta penilaian keberhasilannya. Pembelajaran sebagai suatu yang kompleks dan terintegrasi meliputi; manusia, ide, peralatan, dan organisasi untuk menganalisis masalah yang menyangkut semua aspek belajar, serta merancang, melaksanakan, menilai, dan mengelola pemecahan masalah tersebut. Dalam pemecahan masalah itu terwujud dalam bentuk sumber belajar yang didesain dan digunakan untuk keperluan belajar, sumber-sumber belajar ini meliputi: pesan, orang, bahan, peralatan, tekhnik, dan latar.

Suasana pembelajaran yang dikembangkan mempunyai pengaruh yang sangat besar terhadap keberhasilan pembelajaran dan gairah belajar peserta didik. Kualitas dan keberhasilan pembelajaran sangat dipengaruhi oleh salah satunya ketepatan dalam memilih model pembelajaran. Ketepatan dalam memilih model pembelajaran akan berpengaruh terhadap hasil dan keberhasilan dalam capaian pembelajaran. Belajar mencakup bidang kognitif, afektif dan psikomotorik yang harus dikuasi mahasiswa setelah mengikuti proses perkuliahan. Hasil belajar mencerminkan tujuan pada tingkat tertentu yang berhasil dicapai oleh peserta didik yang dinyatakan dengan angka atau huruf. Hasil belajar yang dimaksudkan adalah nilai kemampuan setelah evaluasi sebagai perwujudan dari upaya yang telah dilakukan selama proses belajar mengajar berlangsung (Sudjana, 2017).

Belajar dikatakan berhasil, apabila tujuan instruksional dapat dicapai, karena keberhasilan pembelajaran dapat dinilai dari perubahan tingkah laku dari sebelum dan sesudah memperoleh pengalaman belajar. Hasil belajar diartikan sebagai sejumlah pengalaman yang diperoleh peserta didik yang mencakup kognitif, afektif dan psikomotorik (Rusman, 2017). Penilaian hasil belajar merupakan kegiatan untuk mengambil keputusan dengan menggunakan informasi yang diperoleh melalui pengukuran tes maupun non tes. Penilaian merupakan bagian internal dalam pembelajaran yang sering digunakan yakni pengukuran, evaluasi, tes dan penilaian itu sendiri (Yaumi, 2013).

Dalam pembelajaran terdapat penilaian dengan menggunakan evaluasi untuk mengetahui tingkat keberhasilan peserta didik dengan memberikan tes atau tugas dapat dalam bentuk tes tulis, lisan maupun perbuatan. Untuk mengetahui nilai terkait tes yang telah diberikan sebagai evaluasi, pendidik melakukan tindakan pengukuran. Dimana pengukuran bertujuan untuk mengetahui hasil belajar. Tanpa adanya pengukuran, pendidik tidak akan bisa menentukan hasil belajar dalam pembelajaran. Terkait Penilaian hasil belajar adalah proses 
pemberian nilai terhadap hasil-hasil belajar yang dicapai peserta didik dengan kriteria tertentu yang mengisyaratkan bahwa objek yang dinilai adalah hasil belajar (Sudjana, 2017). Hasil belajar merupakan kemampuan yang dimiliki peserta didik setelah ia menerima pengalaman belajarnya, melalui proses penilaian terhadap hasil belajar yang dapat memberikan informasi kemajuan peserta didik dalam kegiatan pembelajaran (Rusman, 2017).

Hasil belajar menjadi ukuran atas tercapainya tujuan dari proses belajar. Oleh karena itu, proses belajar perlu diilai atau dievaluasi untuk mengetahui ketercapaian tujuan dari proses membelajaran. Evaluasi merupakan proses penggunaan informasi untuk membuat pertimbangan seberapa efektif suatu program telah memenuhi kebutuhan peserta didik (Yusuf, 2015). Evaluasi yang diberikan berupa tes tulis, lisan mapun perbuatan. Dapat disimpulkan bahwa penilaian hasil belajar merupakan suatu proses dalam pemberian nilai terhadap hasil belajar yang dilakukan kepada mahasiswa setelah menerima pengalaman belajarnya dan kemudian melalui proses penilaian dengan evaluasi tersebut dosen menentukan capaian hasil belajar mahasiswa.

Penggunakan model pembelajaran merupakan salah satu komponen penting dalam pembelajaran. Model pembelajaran yang efektif akan sangat membantu dalam proses pembelajaran sehingga tujuan pembelajaran akan lebih mudah tercapai. Selain itu, model pembelajaran juga dapat memberikan informasi yang berguna bagi peserta didik dalam proses pembelajaran. Model pembelajaran adalah suatu rencana atau pola yang dapat digunakan untuk membentuk kurikulum (rencana pembelajaran jangka panjang), merancang bahan pembelajaran, dan membimbing pembelajaran di kelas atau yang lain (Rusman, 2012). Model pembelajaran tersebut merupakan pola umum perilaku pembelajaran untuk mencapai tujuan pembelajaran yang diharapkan. Mengenai uraian di atas, sumber lain mengemukakan bahwa, Model pembelajaran adalah bentuk pembelajaran yang tergambar dari awal sampai akhir yang disajikan secara khas oleh guru. Dengan kata lain, model pembelajaran merupakan bungkus atau bingkai dari penerapan suatu pendekatan, metode, strategi, dan tehnik pembelajaran (Helmiati, 2016).

Model pembelajaran yaitu bentuk pembelajaran yang tergambar dari awal hingga akhir. Model pembelajaran adalah suatu perencanaan atau pola yang digunakan sebagai pedoman dalam merencanakan pembelajaran dikelas atau pembelajaran tutorial (Afandi, et al. 2013). Model pembelajaran merupakan suatu perencanaan untuk merencakan pembelajaran yang merupakan bingkai dari penerapan suatu pendekatan, metode, strategi, dan tehnik pembelajaran.

Model pembelajaran memiliki peran strategis dalam upaya meningkatkan hasil belajar peserta didik sebagai contoh model pembelajaran contextual teaching learning. Model ini adalah model pembelajaran yang menghubungkan materi dengan keadaan nyata. Model pembelajaran contextual teaching learning (CTL) dimulai dengan sajian atau tanya jawab lisan yang terkait dengan dunia nyata 
(Ngalimun, 2017). Model pembelajaran contextual teaching learning (CTL) merupakan pembelajaran yang digunakan untuk memudahkan memahami materi pelajaran dengan mengaitkan dengan kehidupan sehari-hari (Aqib, 2013). Berdasarkan pendapat tersebut dapat ditarik kesimpulan model pembelajaran contextual teaching learning (CTL) merupakan model pembelajaran yang mengaktifkan peserta didik dalam membangun pengetahuannya dan mengaitkan makna materi yang dimulai dengan sajian atau tanya jawab lisan dalam konteks kehidupan sehari-hari.

Selain model tersebut di atas, ada juga model sains teknologi masyarakat. Model ini termasuk model pembelajaran konstruktivisme yang berlandaskan berfikir (filosofi) membangun pengetahuan melalui kegiatan eksplorasi dan diskusi serta mengaplikasikan kepada situasi baru dan mengintegrasikan pengetahuan baru yang diperoleh dengan membangun intelektual yang sebelumnya ada. Model sains teknologi masyarakat merupakan suatu model pembelajaran yang mengaitkan antara sains dan teknologi serta pemanfaatannya bagi masyarakat (Lestari, et al. 2016). Sains Teknologi Masyarakat merupakan model pembelajaran yang bertujuan menyajikan konteks dunia nyata dalam pendidikan dan pendalaman sains (Gusfarenie, 2013). Maka dari itu model sains teknologi masyarakatdapat dikatakan sebagai suatu model pembelajaran yang mengaitkan antara ilmu pengetahuan berupa hal-hal baru (inovasi) teknologi serta pemanfaatannya pada masyarakat tertntu yang bertujuan menyajikan konteks dunia nyata dalam pendidikan.

Tujuan penelitian ini adalah untuk mengetahui efektifitas model pembelajaran contextual teaching learning dan model sains teknologi masyarakat terhadap hasil belajar mahasiswa pada mata kuliah difusi inovasi pendidikan

\section{METODE PENELITIAN}

Penelitian ini adalah penelitian kuantitatif dengan pendekatan eksperimen semu dengan pre-experimental design yaitu two-group pretest-posttest design. Metode penelitian eksperimen merupakan, metode penelitian yang digunakan untuk mencari pengaruh treatment (perlakuan) tertentu (Sugiyono, 2017). Penelitian pada dasarnya merupakan suatu pencarian menghimpun data, mengadakan pengukuran, pengaruh dan analisis, beberapa peneliti menyebutkan sebagai tradisi penelitian (research traditions). Penelitian kuantitatif sebagai suatu proses menemukan pengetahuan yang menggunakan data berupa angka sebagai alat menganalisis keterangan mengenai apa yang ingin diketahui (Kuntjojo, 2009).

Adapun pengumpulan data dilakukan dengan tes, yaitu untuk mengetahui kemampuan mahasiswa. Tes merupakan seperangkat rancangan atau stimulus yang diberikan kepada peserta didik untuk mendapatkan jawaban yang mendasar untuk penetapan skor (Margono, 2004). Tes merupakan alat yang digunakan untuk menilai dan mengukur hasil belajar peserta didik (Sudjana, 2011). Tes 
dalam konteks penelitian ini yaitu untuk mengetahui hasil belajar mahasiswa dengan cara menilai dan mengukur hasil belajarnya.

Selain tes, metode dokumentasi juga digunakan sebagai pendukung untuk mencatat kegiatan pada saat melakukan penelitian dan untuk memperoleh data. Dokumentasia dalah ditujukan untuk memperoleh data langsung dari tempat penelitian melalui buku-buku yang relevan, peraturan-peraturan, laporan kegiatan, foto-foto, film dokumenter data yang relevan (Sudaryono, 2016). Dokumentasi adalah benda-benda tertulis (Suharsimi, 2014). Dari kedua pendapat tersebut, maka yang dimaksud dengan dokumentasi adalah suatu cara yang dilakukan dengan mencatat keterangan-keterangan yang terdapat dalam dokumen-dokumen salah satunya seperti daftar hadir, nilai matakuliah mahasiswa yang terdahulu dafat harid belajar mengajar dan data yang relevan lainnya.

Dalam penelitian ini digunakan juga metode wawancara untuk mengetahui tanggapan mahasiswa. Wawancara merupakan suatu kegiatan seorang individu atau kelompok dalam mencari informasi dengan melakukan tanya jawab. Wawancara merupakan proses interaksi dengan percakapan tatap muka antara interviewer dengan interviewee (Yusuf, 2015). Wawancara dapat digunakan untuk menilai hasil dan proses belajar (Sudjana, 2017). Terkait dengan uraian di atas, ahli lain mempertegaskan bahwa Wawancara merupakan suatu cara pengumpulan data yang digunakan untuk memperoleh informasi langsung dari sumbernya (Sudaryono, 2016). Dari pendapat-pendapatdi atas, maka yang dimaksud dengan wawancara dalam penelitian ini yaitu cara untuk memdapatkan data dan informasi mengenai tanggapan mahasiwa terhadap proses pembelajaran matakuliah difusi inovasi pendidikan.

Metode observasi juga diterapkan dalam penelitian ini untuk mengamati gambaran situasi proses perkuliahan. Metode observasi adalah metode pengumpulan data dengan aktivitas melakukan pengamatan terhadap suatu proses kegiatan pembelajaran. Observasi yaitu kegiatan melakukan pengamatan secara langsung ke objek penelitian untuk melihat dari dekat kegiatan yang dilakukan, (Sudaryono, 2016). Observasi atau pengamatan sebagai alat penilaian banyak digunakan untuk mengukur tingkahlaku individu ataupun proses terjadinya suatu kegiatan yang dapat diamati (Sudjana, 2016). Senada dengan pendapat sebelumnya, menurut Hadi dalam sebuah sumber menyatakan bahwa, observasi merupakan suatu proses kompleks, yang tersusun dari berbagai proses biologis dan psikhologis yaitu pengamatan dan ingatan (Sugiyono, 2017). Dari uraian di atas, disimpulkan bahwa metode observasi adalah suatu proses kompleks, yang tersusun dari berbagai proses biologis dan psikhologis dan sebagai alat penilaian yang digunakan untuk mengetahui tingkah laku individu tiap diri mahasiswa.

\section{HASIL DAN PEMBAHASAN}

Berdasarkan hasil penelitian yang dilakukan, pengukuran yang digunakan dalam penelitian ini adalah hasil belajar dalam ranah kognitif yaitu hasil post-test 
yang diberikan kepada dua kelompok eksperimen yaitu kelompok model 1 dan kelompok model 2. Pada penelitian ini dilakukan pengambilan pre-test dan posttest menggunakan metode tes pada matakuliah difusi inovasi pembelajaran yang diberikan pada kelompok yang diberi perlakuan yang berbeda yaitu model pembelajaran Sains Teknologi Masyarakat pada kelompok 1 dan modelpembelajaran contextual teaching learning pada kelompok 2.

Sebelum dihitung dengan rumus t-test pada hasil akhir perbandingan model pembelajaran contextual teaching learning dengan sains teknologi masyarakat, terlebih dahulu dilakukan pembuktian adanya perbandingan antara pre-test dan pos-test kedua model pembelajaran. Dalam nilai rata-rata $\left(\overline{x_{1}}\right)$ pretest pada sains teknologi masyarakat ditemukan nilai sebesar 79,273 dan rata-rata $\left(\overline{x_{1}}\right)$ pos-test sebesar 850,503 . Sedangkan rata-rata $\left(\overline{x_{2}}\right)$ pre-test pada contextual teaching learing ditemukan nilai sebesar 65,454 dan rata-rata $\left(\overline{x_{2}}\right)$ pos-test sebesar 1621,57. Selain itu terdapat peningkatan nilai pada gain (d) dimana gain pada $\mathrm{d}_{1}>\mathrm{d}_{2}$ yaitu $142>129$.

Ini menunjukkan bahwa $\left(\overline{x_{1}}>\overline{x_{2}}\right)$ atau $1621,57>850,503,\left(\mathrm{~d}_{1}>\mathrm{d}_{2}\right)$ yaitu 142>129, hasil penelitian ini menunjukkan bahwa terdapat adanya perbedaan antara pre-test dan post-tes dari kedua model pembelajaran. Setelah menghitung perbandingan dari pre-test dan pos-test kedua model pembelajaran, kemudian dicari perbandingan antara kedua model tersebut dengan membandingkan postest. Sesuai dengan data yang diperoleh dan setelah dianalisis diketahui jumlah $\mathrm{X}_{1}$ (pos-test pada model pembelajaran sains teknologi masyarakat) $=942$ dan $X_{2}$ (pos-test pada modelpembelajaran contextual teaching learning) $=849$ sedangkan $\overline{\mathrm{x}_{1}}$ (rata-rata nilai pada model sains teknologi masyarakat $=1621,57$ dan $\overline{\mathrm{x}_{2}}$ (ratarata nilai pada model pembelajaran contextual teaching learning $)=850,503$. Nilai varian data diperoleh sebesar $\mathrm{v}_{1}=85,05$ dan $\mathrm{v}_{2}=162,15$.

Setelah semua nilai telah diketahui maka dari hasil uji $t$-test menunjukan nilai $t_{\text {hitung }}$ sebesar $\mathrm{t}=2,915$ pada taraf signifikansi $5 \%$ dan d.b $=20$. Besarnya angka batas penolakan hipotesis nihil (Ho) yang dinyatakan dalam tabel distribusi $t_{\text {tabel }}$ adalah 2,086 yang menunjukan bahwa nilai $t_{\text {hitung }}$ lebih besar dari pada nilai $t_{\text {tabel }}(\mathrm{t}=2,915>2,086)$. Karena $t_{\text {hitung }}$ lebih besar dari $t_{\text {tabel }}$ maka penelitian ini signifikansi. Hal ini berarti bahwa hipotesis nihil (Ho) yang diajukan ditolak dan sebaliknya hipotesis alternatif (Ha) yang diajukan diterima, maka dapat ditarik kesimpulan bahwa " Ada pengaruh model pembelajaran contextual teaching learning dan model sains teknologi masyarakat terhadap hasil belajar mahasiswa pada matakuliah Difusi Inovasi Pendidikan.

Berdasarkan hasil hitung juga model pembelajaran sains teknologi masyarakat memiliki nilai rata-rata lebih tinggi dibandingkan dengan nilai rata model pembelajaran contextual teaching learning. Ini disebabkan karen model sains teknologi masyarakat dapat membantu mahasisiswa lebih memahami materi karena terkait dengan permasalahan yang ditemukan dikehidupan nyata sehingga mahasiswa menjadi lebih aktif dalam proses belajar mengajar. Sedangkan model 
pembelajaran contextual teaching learning berorientasi pada pemecahan masalah dengan menggunakan motede diskusi. Mahasiswa menemukan kesulitan dalam berfikir kritis untuk membangun dan mengembangkan pengetahuannya sendiri. Maka dalam hal ini dapat disimpulkan bahwa terdapat perbedaan hasil belajar antara mahasiswa yang menggunakan model pembelajaran contectual teaching learning dengan mahasisa yang menggunakan model sains teknologi masyarakat.

\section{SIMPULAN}

Berdasarkan hasil penelitian dan pembahasan dapat disimpulkan ada pengaruh model pembelajaran contextual teaching learning dan model sains teknologi masyarakat terhadap hasil belajar mahasiswa pada matakuliah difusi inovasi pendidikan. Adapun bila dilihat dari tingkat efektifitas kedua model pembelajaran, model pembelajaran sains teknologi masyarakat lebih efektif bila dibanding dengan model pembelajaran contextual teaching learning pada mata kuliah Difusi Inovasi Pendidikan.

\section{DAFTAR PUSTAKA}

Afandy, (2013). Model dan Metode Pembelajaran di Sekolah. Semarang: UNISSULA PRESS.

Aqib, Z. (2013). Model-Model, Media, dan Strategi Pembelajaran Kontekstual (Inovarif). Bandung: Yrama Widya.

Gusfarenie, D. (2013). Model Pembelajaran Sains Teknologi Masyarakat (STM). Jurnal Penelitian

Helmiati. (2016). Model Pembelajaran. Pekanbaru: Aswaja Pressindo.

Kundjojo. (2009). Metodologi Penelitian. Kediri: Universitas Nusantara PGRI Kediri.

Lestari, H. (2016). Penerapan Model Pembelajaran Sains Teknologi Masyarakat (STM) untuk Meningkatkan Hasil Belajar Fisika Siswa Kelas VIII SMPN 3 Mataram. Jurnal Penelitian. Universitas Mataram.

Margono. (2014). Metodologi Penelitian Pendidikan: Komponen MKDK. Jakarta: Rineka Cipta.

Ngalimun. (2017). Startegi Pendidikan. Yogyakarta: Parama Ilmu.

Rusman. (2017). Belajar dan Pembelajaran Berorientasi Standar Proses Pendidikan. Bandung: KENCANA.

Sudaryono. (2016). Metode Penelitian Pendidikan. Penerbit: Kencana.

Sudjana. (2017). Penilaian Hasil Proses Belajar Mengajar. Bandung: PT Remaja Rosdakarya.

Sugiyono. (2017). Metode Penelitian Kuantitatif Kualitatif Dan R\&D. Bandung: Alfabeta.

Suharsimi. (2014). Prosedur Penelitian Suatu Pendekatan Praktik. Jakarta: Rineka Cipta.

Yaumi, M. (2013). Prinsip-Prinsip Desain Pembelajaran. Jakarta: KENCANA.

Yusuf, M. (2015). Assesment dan Evaluasi Pendidikan. Jakarta: KENCANA. 